\section{Inhibition of Rat Embryo Histidine Decarboxylase by Epoxyquinomicins}

\author{
NAOKI MATSUMOTO ${ }^{\mathrm{a}}$, NAOKI AgAta ${ }^{\mathrm{b}}$, Hiroshi KUBOKI ${ }^{\mathrm{b}}$, \\ Hironobu IINUMA ${ }^{a}$, TSUTOMU SAWA ${ }^{\text {a }}$, TOMIO TAKEUCHI ${ }^{\mathrm{a}}$ \\ and KAZUO UMEZAWA ${ }^{\mathrm{C}}$ \\ ${ }^{\text {a }}$ Institute of Microbial Chemistry, \\ 3-14-23 Kamiosaki, Shinagawa-ku, Tokyo 141-0021, Japan \\ ${ }^{\mathrm{b}}$ Central Research Laboratories, Mercian Corporation, \\ 4-9-1 Johnan, Fujisawa, Kanagawa 251-0057, Japan \\ ${ }^{\mathrm{c}}$ Department of Applied Chemistry, Faculty of Science and \\ Technology, Keio University, \\ 3-14-1 Hiyoshi, Kohoku-ku, Yokohama 223-0061, Japan
}

(Received for publication February 14, 2000)

Epoxyquinomicins A, B, C and D were first isolated from Amycolatopsis sp. MK299-95F4 as weak antibiotics (Fig. $1)^{1}$. Subsequent studies on their biological activities revealed that these compounds inhibited type II collageninduced arthritis in $v i v o^{2}$. Epoxyquinomicins showed low acute toxicity in mice by intraperitoneal administration with the $\mathrm{LD}_{50}$ values of $25,50,100$, and $100 \mathrm{mg} / \mathrm{kg}$ for epoxyquinomicins A, B, C, and D, respectively. Therefore, these epoxyquinomicins are unique candidates for antiinflammatory agents. The mode of action appears to be different from that of common NSAIDs (non-steroidal antiinflammatory drugs) ${ }^{3)}$, since epoxyquinomicins $\mathrm{C}$ and $\mathrm{D}$ did not inhibit cyclooxygenase- 1 at the concentration of $300 \mu \mathrm{M}$. The mechanism of the antiarthritic effect has not been elucidated for epoxyquinomicins.

Histidine decarboxylase is considered to be involved in the mechanism of inflammation by producing histamine. Lecanoric acid was isolated from a fungus as a histidine decarboxylase inhibitor ${ }^{4)}$. A synthetic analogue, SD-170 (Fig. 2), with a peptide bond in place of the ester bond of lecanoric acid, was 150 times stronger than lecanoric acid in the inhibition of histidine decarboxylase ${ }^{5)}$. SD-170 inhibited delayed-type hypersensitivity in mice $^{5)}$ and phorbol ester-induced tumor promotion in mice ${ }^{6}$. In view of the structural similarity between epoxyquinomicins and peptide-type lecanoric acid analogues, we studied the inhibition of histidine decarboxylase ${ }^{7 \sim 9}$ by epoxyquinomicins.

As shown in Fig. 3, all of epoxyquinomicins tested concentration-dependently inhibited rat embryo histidine decarboxylase. Among them, epoxyquinomicins $\mathrm{B}$ and $\mathrm{C}$ showed potent inhibitions with $\mathrm{IC}_{50} \mathrm{~s}$ of 0.003 and $0.37 \mu \mathrm{M}$, respectively. Especially, epoxyquinomicin $\mathrm{B}$ was stronger than the positive control SD-170 $\left(\mathrm{IC}_{50}, 0.069 \mu \mathrm{M}\right)$. On the other hand, epoxyquinomicins $\mathrm{A}$ and $\mathrm{D}$, which have a chlorine atom in the salicyl group, showed relatively weak inhibitions with $\mathrm{IC}_{50} \mathrm{~s}$ of 6.9 and $25 \mu \mathrm{M}$, respectively, suggesting a chlorine atom decreases the inhibitory activity.

NAKAmURA et al. demonstrated that elevated histidine decarboxylase activity exacerbated the arthritis by increasing the number of granulocytes, macrophages and osteoclasts $^{10}$. A histidine decarboxylase inhibitor, hypostamine had a therapeutic effect on adjuvant-induced

Fig. 2. Structure of SD-170.<smiles>O=C(Nc1cc(Cl)c(O)c(Cl)c1)c1ccccc1O</smiles>

Fig. 1. Structures of epoxyquinomicins.<smiles>[R]c1cccc(C(=O)NC2=CC(=O)[C@@]3(CO)O[C@H]3C2=O)c1O</smiles>

epoxyquinomicin $\mathrm{A}: \mathrm{R}=\mathrm{Cl}$ epoxyquinomicin $B: \mathrm{R}=\mathrm{H}$<smiles>[R]c1cccc(C(=O)NC2=CC(=O)[C@]3(CO)O[C@@H]3[C@H]2O)c1O</smiles>

epoxyquinomicin $\mathrm{C}: \mathrm{R}=\mathrm{H}$ epoxyquinomicin $\mathrm{D}: \mathrm{R}=\mathrm{Cl}$ 
Fig. 3. Inhibition of rat embryo histidine decarboxylase by epoxyquinomicins.

O: epoxyquinomicin $\mathrm{A}, \bullet$ : epoxyquinomicin $\mathrm{B}, \triangle$ : epoxyquinomicin $\mathrm{C}, \boldsymbol{\Delta}$ : epoxyquinomicin $\mathrm{D}, \square: \mathrm{SD}-170$

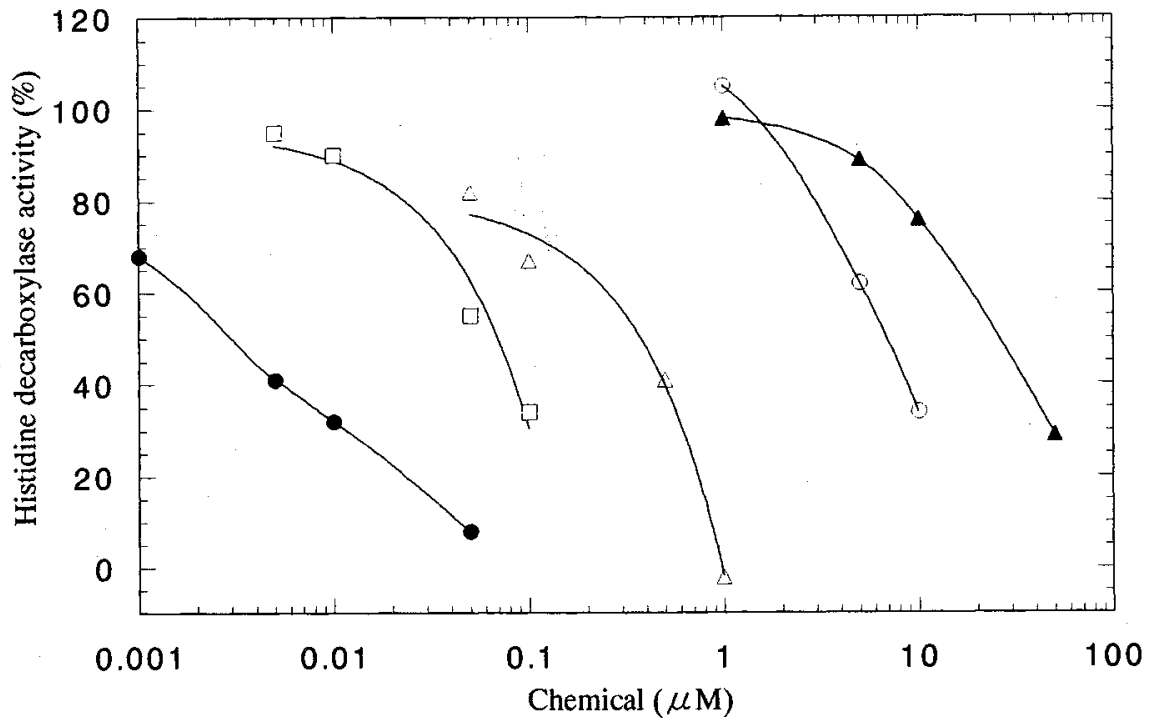

$\operatorname{arthritis}^{11)}$. Therefore, the antiarthritic effect of epoxyquinomicins in vivo may be partly due to the inhibition of histidine decarboxylase.

Thus, epoxyquinomicins $\mathrm{B}$ and $\mathrm{C}$ are new naturally occurring histidine decarboxylase inhibitors.

\section{Experimental}

\section{Preparation of Histidine Decarboxylase}

A crude fraction containing histidine decarboxylase was prepared from fetal rats as described by WATANABE et $a l .^{7)}$. Pregnant rats (purchased from Charles River Japan, Inc.) were decapitated 16 days after mating, and their litters were collected. Whole fetal rats $(85 \mathrm{~g})$ were homogenized for 2 minutes at $0^{\circ} \mathrm{C}$ in $170 \mathrm{ml}$ of $0.1 \mathrm{M}$ sodium acetate buffer (pH 5.4) containing $0.01 \mathrm{~mm}$ pyridoxal phosphate, $0.2 \mathrm{~mm}$ dithiothreitol, and $1 \%$ polyethylene glycol. The homogenate was then centrifuged at $8,000 \mathrm{rpm}$ for 40 minutes at $0^{\circ} \mathrm{C}$. Ammonium sulfate $(60 \mathrm{~g})$ was added to the supernatant, which was thereafter kept at $0^{\circ} \mathrm{C}$ for 15 minutes. The precipitate obtained by centrifugation at $8,000 \mathrm{rpm}$ for 20 minutes was dissolved in $50 \mathrm{ml}$ of $0.02 \mathrm{M}$ potassium phosphate buffer ( $\mathrm{pH} 7.0$ ) containing $0.01 \mathrm{mM}$ pyridoxal phosphate, $0.2 \mathrm{~mm}$ dithiothreitol, and $1 \%$ polyethylene glycol, and dialyzed against $500 \mathrm{ml}$ of the same potassium phosphate buffer overnight at $7^{\circ} \mathrm{C}$. The crude histidine decarboxylase preparation thus obtained was used for enzyme reaction.

Histidine Decarboxylase Assay

Histidine decarboxylase assay was carried out, as also described by WATANABE et $a l^{7}{ }^{7}$. The reaction mixture contained $100 \mu \mathrm{l}$ of $0.25 \mathrm{mM}$ histidine, $100 \mu \mathrm{l}$ of the above enzyme preparation, and inhibitor in $1 \mathrm{ml}$ of $0.2 \mathrm{M}$ potassium phosphate buffer ( $\mathrm{pH}$ 6.8) containing $0.02 \mathrm{mM}$ pyridoxal phosphate, $0.4 \mathrm{~mm}$ dithiothreitol, and $2 \%$ polyethylene glycol. The mixture was incubated at $37^{\circ} \mathrm{C}$ for 5 hours, after which $1 \mathrm{ml}$ of $1 \mathrm{~N} \mathrm{NaOH}$ was added. The mixture was saturated with solid $\mathrm{NaCl}$, and shaken with 2 $\mathrm{ml}$ of $n$-butanol; and then after centrifugation, the organic phase was extracted with $1 \mathrm{ml}$ of $0.1 \mathrm{~N} \mathrm{HCl}$. The extract was finally washed with $1 \mathrm{ml}$ of $n$-heptane. The histamine content in the acid extract was estimated by the method of SHORE $^{8)}$. A $80 \mu \mathrm{l}$ volume of $10 \mathrm{~N} \mathrm{NaOH}$ was added to the $\mathrm{HCl}$ whole extract, followed by $66 \mu \mathrm{l}$ of $1 \%$ $o$-phthalaldehyde-methanol solution (OPT reagent). After 5 minutes, the mixture was acidified with $150 \mu 1$ of $3.5 \mathrm{~N}$ $\mathrm{H}_{3} \mathrm{PO}_{4}$. An aliquot $(200 \mu \mathrm{l})$ was then transferred to a $96-$ well microplate, and the fluorescence at $460 \mathrm{~nm}$ resulting from excitation of $360 \mathrm{~nm}$ was measured with a CytoFluor 2350 multiwell fluorescence plate reader. The calibration curve showed linear correlation between the fluorescence values and $0 \sim 40 \mu \mathrm{M}$ histamine. The extraction efficiency was $76 \%$. 


\section{References}

1) Matsumoto, N.; T. Tsuchida, M. Umekita, N. Kinoshita, H. Innuma, T. SaWa, M. Hamada \& T. TAKEUCHI: Epoxyquinomicins, new antibiotics from Amycolatopsis. I. Taxonomy, fermentation, isolation and antimicrobial activities. J. Antibiotics 50: 900 905, 1997

2) Matsumoto, N.; H. Innuma, T. Sawa, T. Takeuchi, S. Hirano, T. Yoshioka \& M. IshizuKa: Epoxyquinomicins, new antibiotics from Amycolatopsis. II. Effect on type II collagen-induced arthritis in mice. J. Antibiotics 50: 906 -911, 1997

3) Wallace, J. L.: Mechanisms of nonsteroidal antiinflammatory drug (NSAID) induced gastrointestinal damage-potential for development of gastrointestinal tract safe NSAIDs. Can. J. Physiol. Pharmacol. 72: 1493 1498, 1994

4) Umezawa, H.; N. Shibamoto, H. Naganawa, S. AyuKaWA, M. Matsuzaki \& T. TAKeUChI: Isolation of lecanoric acid, an inhibitor of histidine decarboxylase from a fungus. J. Antibiotics 27: 587 596, 1974

5) Umezawa, K.; S. Muramatsu, M. Ishizuka, T. SaWa, T. TAKEUCHI \& T. MATSUSHIMA: Inhibition of histidine decarboxylase and tumour promoter-induced arachidonic acid release by lecanoric acid analogues. Biochem. Biophys. Res. Commun. 110: 733 739, 1983

6) Umezawa, K.; T. Matsushima, T. Sawa, T. Takeuchi \& I. HIRONO: Inhibition of tumor promotion by a lecanoric acid analogue. Experientia 40: 100 101, 1984

7) Watanebe, T.; H. Nakamura, L. Y. Liang, A. YAMATODANI \& H. WADA: Partial purification and characterization of L-histidine decarboxylase from fetal rats. Biochem. Pharmacol. 28: 1149 1155, 1979

8) Shore, P. A.; A. Burkhalter \& V. H. Cohn: A method for the fluorometric assay of histamine in tissues. J. Pharmacol. Exp. Ther. 127: 182 186, 1959 '

9) ENDO, Y.: A method for the assay of histidine decarboxylase activity. Folia Pharmacol. Jpn. (Nippon Yakurigaku Zasshi) 112: 307 314, 1998

10) Nakamura, M.; T. Ando, M. Abe, K. Kumagai \& Y. ENDO: Contrast between effects of aminobisphosphonates and nonaminobisphosphonates on collageninduced arthritis in mice. Br. J. Pharmacol. 119: 205 212, 1996

11) Pelczarska, A.: Treatment of adjuvant arthritis in rats with the histidine decarboxylase inhibitor hypostamine. J. Pharm. Pharmacol. 21: 692 693, 1969 